\title{
PARIS HABITAT'S EXPERIENCE OF URBAN REGENERATION TO CREATE AFFORDABLE HOUSING
}

\author{
Stéphane Dauphin and Hélène Schwoerer
}

\section{Introduction: Living in Paris}

Like the world's other great capital cities, the housing market in the heart of Paris is under great strain, with purchase prices exceeding $€ 10,000 / \mathrm{m}^{2}$ and average monthly rent reaching $€ 27 / \mathrm{m}^{2}$. The development of tourism through Airbnb and second homes, which take thousands of homes away from families, and the many empty accommodation units are aggravating the situation, while the regulatory tools to control the housing market are inadequate. Inspired by Vienna's achievements in social housing - a city that all social classes can call home-the local authorities in Paris are committed to design and build an inclusive city with diverse housing opportunities. A long-term strategy and strong intervention in housing markets are required if these goals are to succeed. In particular, this entails a command of real estate performance, price regulation instruments (for rental properties as well as those related to affordable home ownership) and the market.

Many cities in Europe (London, Berlin, Budapest, Riga) and Asia (Taipei) which sold off their social housing stock and relied on market regulation alone in the 1980s and 1990s are now reassessing those decisions given the current situation (gentrification of cities, exclusion of lower and middle classes, etc.). They are investing massively in affordable housing and are adopting market regulation instruments (rent control, Airbnb prohibition, etc.) (Figure 9.1).

Today, $21 \%$ of the 1,160,000 primary residences in Paris are public housing units. Given the financialisation of the housing sector, the attractiveness of Paris and its soaring property prices, the city's low-income and middle-class families can only continue to live there if the local authorities demonstrate a strong desire to intervene and if market regulation is established. Quality of life, wealth, the variety of its heritage and economic momentum make Paris an attractive city for most people: from the richest to the most vulnerable. Such a high level of attractiveness and numerous potential investors — housing seen as a safe investment — combined with the rarity of both real estate and land opportunities, mean that available accommodation in Paris is under great strain.

Therefore, in 2001, the City of Paris authorities committed to an ambitious, interventionist policy to reshape the housing market and ensure that low-income and middle-class households can access decent housing. However, the metropolis' housing crisis and its consequences for 


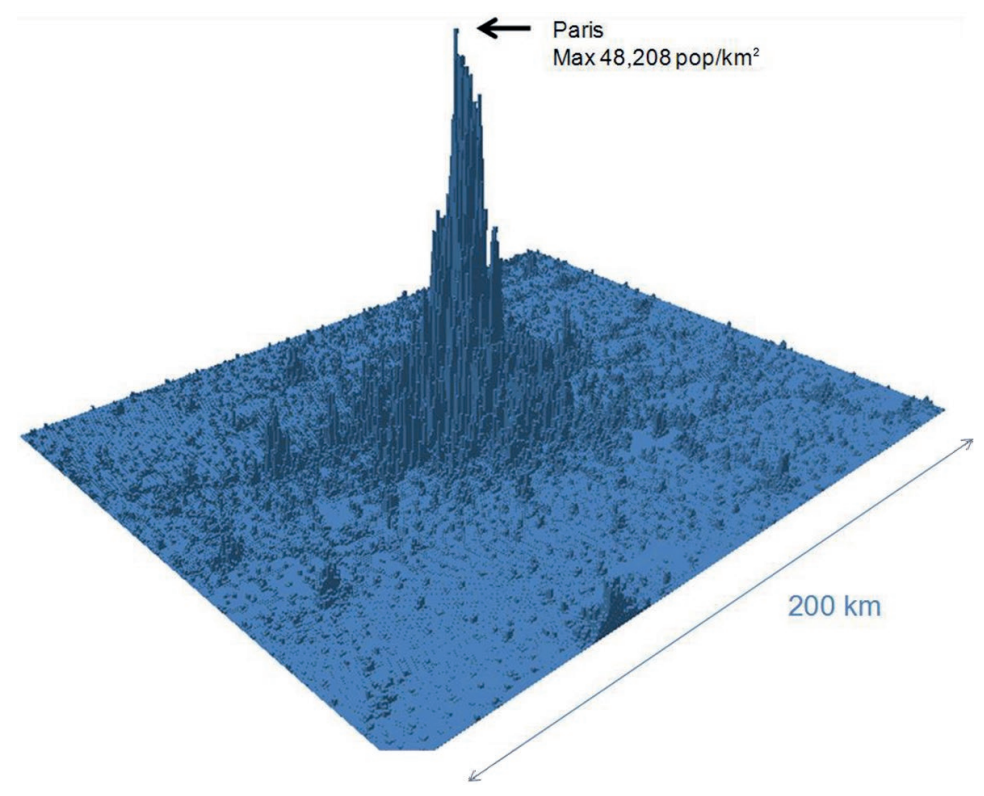

FIGURE 9.1 Paris - High-Density City.

Note: Calculations of OCDE based on Landscan database, 2009.

Source: City of Paris/Paris Habitat.

society remain a serious concern. Hence, the City of Paris authorities and Paris Habitat, the capital's main social housing provider, continue to promote social diversity. The aim is to act along the housing spectrum, from housing for the most impoverished to intermediary housing, paying particular attention to the social mix (Houdard, 2009). Finding effective answers to the demand for housing in Paris is a considerable challenge given the compounded physical and financial constraints in a very high-density area. And yet, Paris remains attractive for young adults, students, executives, low-income and even impoverished families who work there but live far away. Indeed, to this day, more than 249,000 households are waiting for social housing in Paris, nearly 135,000 of which already live in the city (APUR, 2014).

\section{Adapting Provision to the Diverse Needs of Households}

Since 2001, particular effort has been made to support the development of social housing; nearly 110,000 accommodation units were funded between 2001 and 2018. And given the issues surrounding social diversity and unmet demand, the city authorities intend to exceed the goals set down in the SRU Law on Urban Solidarity and Renewal whereby $25 \%$ of main residences should be in the form of social housing (Bacque \& Gauthier, 2011). They seek to achieve $30 \%$ between now and 2030.

To meet the expectations of all households, the social housing units funded since 2001 can be split into three distinct categories based on the applicable rent and on the income ceilings the households must meet to could qualify for them:

- PLAI (Prêt Locatif Aidé d'Intégration or Assisted Integration Rental Loan): average rent of $€ 6 / \mathrm{m}^{2} / \mathrm{month}$; annual income for one person: $€ 13,000$; and for a couple with one child: $€ 28,000$; 
- PLUS (Prêt Locatif à Usage Social or Rental Loan for Social Housing Purposes): average rent of $€ 7 / \mathrm{m}^{2} /$ month; annual income for one person: $€ 23,700$; and for a couple with one child: $€ 46,500$;

- PLS (Prêt Locatif Social or Social Housing Rental Loan): average rent of $€ 13.40 / \mathrm{m}^{2} / \mathrm{month}$; annual income for one person: $€ 30,800$; and for a couple with one child: $€ 60,500$.

These income ceilings are set by the State and can be adapted depending on the region, residents' incomes and the situation in the different housing markets (Driant, 2014). All accommodation units are allocated to households whose incomes are $60-80 \%$ below the ceilings indicated (PLAI, PLUS, PLS).

To respond to the diversity of households - families with children, students, dependent elderly people and the vulnerable- $68 \%$ of the housing units funded represent family accommodation units and 32\% specific accommodation units. The latter category includes accommodation for dependent elderly people, temporary accommodation, guest houses, accommodation for young workers, Emergency Housing Centres and so forth. The balance of the three main categories is $40 \%$ to PLUS, $30 \%$ to PLAI and $30 \%$ to PLS. Further, more than $50 \%$ of Paris' residential housing stock consists of small units. This makes it very difficult for families with children to find accommodation suited to their family and their income. Therefore, all social housing development projects include more than $50 \%$ of $2+$ bedroom apartments.

On the other hand, the so-called 'upper' middle class also faces increasing problems to find affordable housing. Combined with the public goal to promote social diversity, this situation has led local authorities to develop intermediary accommodation units. These developments have been located in chosen geographical areas in order to balance the social mix (Houdard, 2009). These housing units targeted to upper-middle-class households are called 'PLI - Prêt Locatif Intermédiaire' or Intermediary Rental Loan- units):

- PLI: average rent of $€ 17 / \mathrm{m}^{2} / \mathrm{month}$; annual income for one person: $€ 42,400$; and for a couple with one child: $€ 76,700$.

\section{Levers for Developing Social Housing}

The City of Paris authorities activate all possible legal provisions to encourage the creation of affordable housing to as many people as possible (Driant, 2014). These provisions include:

- Exercising pre-emption and priority rights;

- Development of public construction projects where at least $60 \%$ of the housing is put aside for the creation of social and intermediary accommodation units (new urban areas on the east side of Paris, near the Seine, and on the northwest, both using land created above railroad tracks);

- Conditions imposed in the Local Urban Development Plan which identify the specific land lots needed to be dedicated to social and intermediary housing;

- Conditions imposed for all private projects greater than $800 \mathrm{~m}^{2}$ located in areas with insufficient social housing to include $30 \%$ of all housing built as social housing or to include $30 \%$ of intermediary housing in the areas without a social housing deficit;

- Encouragement to transform obsolete office buildings and public buildings into social and intermediary housing;

- In the near future, the creation of a community land trust (in French, 'Organisme de foncier solidaire', or socially responsible real estate entity) to develop affordable home ownership. 
A diversity of housing is sought for all projects within each arrondissement (Paris' district). Thus, in arrondissements which already have a large proportion of social housing, PLS, PLI or specific rental accommodation projects will be given preference. The distribution and integration of all the funding categories within a given housing project takes into account the 'SRU [urban solidarity and renewal] rate' of the arrondissement and local rebalancing issues (APUR, 2017). Still, the need for housing cannot be resolved at the scale of Paris alone; answers have to be found within the Greater Paris.

Moreover, the climate emergency and the need to take collective action to confront climate change force us to reassess how we live our lives, in every sense, and how we make cities. We need to reconsider urban density, materials and even the place of nature in the city. These paradigmatic changes are being imposed on us, but they cannot divert us from our goal: the city must be shared and must be accessible to everyone in all our diversity.

\section{An Ambitious Policy in Terms of Quality and Sustainable Housing}

To implement this proactive social and affordable housing policy, the City of Paris authorities rely mainly on three housing providers: Régie Immobilière de la ville de Paris - RIVP (60,000 housing units), Elogie/Siemp (27,000 housing units) and Paris Habitat.

Paris Habitat is the largest Public Housing Office (office public de l'habitat or OPH) in France, with nearly 125,000 housing units. Created in 1914, it houses more than one in nine Parisians. It invests nearly half of its average budget of approximately $€ 1$ billion in developing, renovating and maintaining its properties. On average, Paris Habitat's properties are 74 years old. They are strongly committed to their upkeep: adapting themselves to climate change, updating their facilities, reducing their energy consumption and combating the economic vulnerability of tenants. The potential value of these properties, which are for the use and enjoyment of all Parisians, is very high, greater than $€ 50$ billion. Paris Habitat also owns 4,000 stores, more than 50,000 parking lots and over a 100 ha of gardens and green spaces. Paris Habitat has a deliberate policy of maintaining ownership of these properties.

Development of social and intermediary housing goes hand in hand with high standards in terms of architectural quality. Hence, Paris Habitat systematically selects projects through architectural competitions and competitive bids. Since 2007, with Paris' first Climate Plan, environmental criteria have become priority goals in new housing projects and regeneration projects: these goals target energy consumption, reduced greenhouse gas effect, creation of green roofs, development of renewable energy, and are formalised in certifications (ISO 50 001, NF Habitat HQE) and charters such as Démoclès and Bois.

Since 2018, the City of Paris has intensified its effort to tackle the climate emergency. In all its construction and renovation programmes, Paris Habitat has undertaken to comply with nine of the 17 UN Sustainable Development Goals to be achieved by 2030. Indeed, all Paris Habitat's development programmes are affected by the issues related to the creation of a post-carbon city by 2050 .

- Energy: be a player in energy transition, thermal renovation and renewable energy;

- Sustainable city: ecological transition of the area; limit the excavation of land, encourage non-carbon movement and transport materials, compensation of residual emissions locally or over another area;

- Climate change: propose solutions to reduce greenhouse gas emissions and adjust to global warming. Reversible building, dry construction, maximise permeable surfaces. Work on improving summer comfort; 
- Resources: engage in responsible consumer practices, circular economy, waste reduction;

- Water: develop sustainable water resources, use of non-drinking water;

- Innovation: use BIM/CIM or optimise performance at a lower cost;

- Life on Earth: create green roofs and walls on buildings, demineralisation of free spaces, preservation of biodiversity;

- Health: clean site, air quality, materials, and so forth;

- Partnership: discuss, pool energy and assess energy production facilities.

\section{Rising to the Challenge: Transformation of the Reuilly Barracks}

Owned by the Ministry of Defence, the Reuilly Barracks (Figure 9.2) occupied two hectares of land in the heart of Paris between Place de la Bastille and Place de la Nation, a well-connected area, served by a dense public transport network (bus, metro) and cycle paths.

Like a hundred other real estate and property lots in Paris, in 2006, these Barracks had been tagged for the development of $50 \%$ social housing in the Local Urban Development Plan. As time went by, the Barracks no longer met the needs of the army. Hence, the State decided to sell them in order to rationalise its real estate holdings.

In 2013, the government adopted The Duflot Law, requesting State-owned real estate to facilitate the creation of social housing in France. This law enabled the State and other large public operators to sell real estate at prices below their market value in order to encourage the creation of social housing. This specific cut allows social housing providers to acquire land or buildings below the local market price and therefore make their projects economically sound (Bacqué \& Gauthier, 2011). The Reuilly Barracks were part of this plan. After extensive negotiations between the City of Paris authorities, the State and Paris Habitat, a memorandum of understanding was agreed upon. It defined the housing programme to be achieved on the parcel

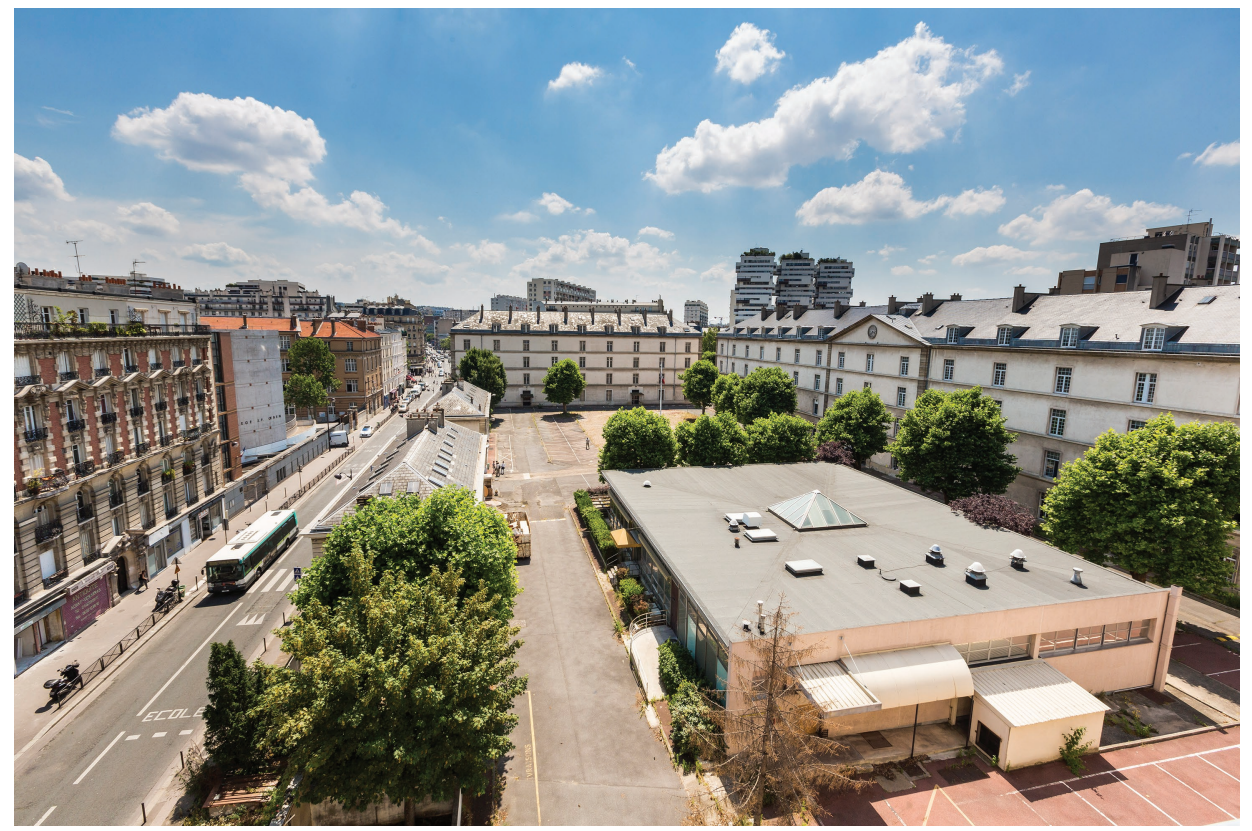

FIGURE 9.2 Historical Military Barracks in Paris.

Source: Paris Habitat, by Cyril Bruneau. 
and the financial conditions for the purchase of this property. The programme stipulated that in order to avoid any speculation, it was agreed that only rental properties would be developed. Given its location, the historical qualities of the existing buildings and the parade ground and its transformation potential, it was decided that the project would include:

- $50 \%$ social housing (family accommodation, PLUS, PLS and PLAI, student accommodation);

- $\quad 20 \%$ intermediary housing (PLI); and

- $\quad 30 \%$ private, rent-controlled accommodation units.

Specific premises for activities including artists' workshops, retail space, a nursery for 66 children and a public garden measuring nearly $5,000 \mathrm{~m}^{2}$ completed the programme.

\section{Financial Arrangement to Develop Sustainable Housing}

First of all, it is essential to recall that access to housing is the responsibility of the State, and mobilisation of its real estate to develop accessible housing programmes was one of its priorities. As early as 2004, the State agreed to sell or rent property in Paris at prices compatible with the financial equilibrium of projects in order to ensure the development of housing and social housing. In the case of the Reuilly barracks, the purchase price was defined taking into account the nature of the various programmes, their respective costs and projected income to reach a global financial equilibrium. Four components were identified:

- Social housing programmes built by refurbishing existing buildings and constructing new ones: $€ 958 \mathrm{~m}^{2}$,

- Intermediary housing programmes through refurbishing and construction: $€ 900 \mathrm{~m}^{2}$;

- Rent-controlled private rental accommodation units: $€ 1,400 \mathrm{~m}^{2}$; and

- $\quad$ Public facilities, retail space: $€ 1,700 \mathrm{~m}^{2}$.

Paris Habitat purchased the Reuilly barracks for $€ 40$ million. The agreement provided that, in the event the income generated by Paris Habitat on the project was higher than expected, Paris Habitat would pay $75 \%$ of this extra income to the State, keeping $25 \%$ as an incentive and/or reimbursement for front-end costs for environmental cleaning of polluted land and partial demolition of existing buildings. This purchase was also bound by an obligation to comply with a precise schedule for the various urban development procedures (impact study, filing of construction permits, etc.) and competitive bidding with regard to the private portion.

In the time that went by between the purchase of this property by Paris Habitat and the beginning of the project itself, the law changed and made it possible for Paris Habitat to sell part of the project to a private investor 'once-completed' (vente sur plans or VEFA). It was the first time a social housing provider, publicly regulated, was going to sell housing units to a private investor. This requires an explanation. In France, many development projects are carried through private promotion, and this is increasingly the case in the construction of social and intermediary housing. The landlord buys the property 'once-completed' and takes no part in the construction project; its sole role is to buy and then manage the property. The new law changed the role of the social housing provider who could thereafter engage in large-scale programmes, guarantee their overall consistency and environmental goals, construct the properties and then in turn sell them, 'once-completed', to a private landlord. Note that it is possible for a social housing provider to undertake this role akin to the one of a private promoter only when private accommodation units account for less than $30 \%$ of the housing units to be developed. 
In order to find the investor that would acquire the rent-controlled, private accommodation units, Paris Habitat organised an open call for tender. This competitive bid laid out clearly the sale conditions, the quality level of the accommodation sold and the requirements set by Paris Habitat both in terms of their management and their future use. Potential buyers had to commit to keep these accommodation units in the private rental sector for a 20 -year period. After these 20 years, Paris Habitat will have the option to purchase the housing units. In the meantime, these accommodation units will be rented out at between $20 \%$ and $30 \%$ below the market rate.

The project was undertaken by Paris Habitat based on this memorandum of understanding which set a constructability goal of $37,163 \mathrm{~m}^{2}$, that is, around 500 accommodation units. This constructability was below the theoretical, maximum constructability that could have been reached according to the Local Urban Development Plan. But this theoretical level would have entailed total demolition of the existing buildings, which was unthinkable. In fact, it was imperative to preserve the historical buildings and the large central space which formed the parade ground. Total demolition of the existing buildings would not have been compatible with the opinion of the 'Architectes des Bâtiments de France', State architects in charge of preserving historical heritage. Paris Habitat undertook a long process of negotiation with this entity. This resulted in a project that protects the legacy of heritage resources and yet allows a higher than expected constructability for 600 accommodation units. Local authorities granted all the urban development permits needed.

In the end, the extra income generated by the project and due to the State exceeded $€ 12$ million:

- $€ 4$ million earned thanks to the additional constructability that Paris Habitat managed to reach, while still respecting architectural and historical heritage requirements; and

- $€ 8$ million thanks to the sale of the 'once-completed' private, rent-controlled rental units: Paris Habitat found an investor for the private units at a better than expected price.

\section{Cooperation and Co-Design to Transform the Reuilly Barracks}

For decades, these military barracks were an enclave in the city, and access was completely denied to the public. Protected by thick walls, the area was cut off from the rest of the neighbourhood. Therefore, before launching the transformation of the site to turn it into a new neighbourhood, it was decided that it should be opened up to the public. Various spaces were entrusted to partners and collectives of artists until construction work began. For nearly two years, the buildings and external spaces have been occupied by:

- Le Centre d'Action Social Protestant which housed 120-180 homeless people and refugees;

- Artistic groups, Gare XP and le Jardin d'Alice, which produced and organised exhibitions and activities;

- The Romanès circus; and

- Hip Hop Citoyen and the Astral theatre.

Through their creativity and their work, these different partners have fully contributed to the opening up of this historical place to the neighbourhood. Today, this is known as 'transitional urban development' or 'transitional urban arrangements'. We expect this model of occupation to develop markedly in the years to come. While it allows spaces to be occupied during the often long and protracted period before the transformation project begins, the unoccupied premises provide a response to emergency situations (accommodation for the homeless, 
refugees, etc.). The City of Paris authorities have adopted a charter to support and encourage this type of transitional arrangements. It was signed in August 2019 by the main operators in the sector (developers, promoters and social housing landlords) working in this area (APUR, 2017).

Construction projects usually coincide with a refusal by residents to accept the transformation of their local environment, particularly when it involves creating social housing. Therefore, this large-scale project required not only to transform existing historical buildings while taking advantage of their intrinsic qualities but also to rethink how a new neighbourhood should be created.

The process involved several steps. First, Paris Habitat organised a competitive bid to select the 'main architect' that would coordinate all the others ('l'architecte coordinateur'). This bid was won by $\mathrm{H} 20$ team who was therefore entrusted with the development of this new neighbourhood and had the task of guaranteeing the correct delivery of the project goals - be they urban, environmental or historical preservation. These main goals had then to be shared with the City of Paris authorities and the various players involved such as the Architectes de Bâtiment de France. Then, six project management teams of architects were chosen for the different projects that compose the whole programme.

Given the scheduling challenges and the ambitious time frame, it was decided to select these architects through a competitive dialogue instead of a regular bid where they would have presented finished projects, which could not have been adapted to guarantee the global harmony of the programme. The competitive dialogue process ensured that projects could be developed simultaneously in a workshop format in collaboration with the various players and residents. In all the construction and renovation programmes it undertakes, Paris Habitat always endeavours to select project management teams of architects with different experiences and backgrounds, each with its unique architectural style. This was the case for the transformation of the Reuilly barracks which was entrusted to six different design and project management teams:

- $\quad$ Lin Architects Urbanits (German team), Package A;

- Lacroix Chessex (Swiss team), Package F;

- Mir (French team), Package D/E;

- Anyoji Beltrando (French team), Package B;

- Charles Henri Tachon (French team), Package B1; and

- NP2F and Office Kersten Geers and David Van Severen (French/Belgian team).

Workshops and co-design between project management teams made it possible to develop the urban project, the positioning of buildings and the relationship between what already existed and the new buildings. This collaborative work resulted in agreement on sizes, materials and colours. Overall coherence was reached through diversity.

Throughout the project development process and until its delivery, a specific place, a 'project house', was put aside for collaborative work and discussions between the project's players and the residents. As needed, the project house could alternatively be used as a design workshop, a conference venue, an exhibition site and an area for negotiation. The various project development phases were presented at public meetings. All the programmes, such as the garden or the future of the retail spaces, were subject to consultation, co-design and local walks with residents and Parisians. Joint development of this project meant that it was possible to go beyond the anticipated constructability with nearly $40,000 \mathrm{~m}^{2}$ created and renovated spaces. All the urban development regulatory procedures (development permit, public consultation, environmental authorisations and the six construction permits) were met favourably and no legal action was taken against them by local residents. This is truly unheard of in Paris. 


\section{Ecological and Social Transformation}

The Reuilly barracks project undoubtedly provides a response to critics of 'Paris being covered in concrete' - critics which also condemn the housing conditions of the most vulnerable and the exodus of families with children who can no longer be housed in Paris for financial reasons. Parisians who demand that the city's population be reduced and only green spaces be developed. Indeed, in our opinion, the Reuilly Barracks project truly reconciles environmental and social emergency concerns.

For many years, private investors impatiently awaited the sale of these Barracks to demolish the existing buildings and 'pour concrete' over this plot of land in the very heart of Paris. Little attention was paid to the intrinsic quality of the buildings, their transformation potential, the urban singularity of the military site and the sensitivity of local residents to their environment (Donzelat, 2012). These property players did not consider the necessity to create a sustainable city (Figure 9.3).

\section{Promotion of the Site's Heritage and History}

For Paris Habitat, preservation of the central empty space and transformation of the old buildings, even if the latter were not exceptional, were obvious. It was a necessity with regard to the sustainable development goals of the project. These buildings were not seen as a constraint, but rather, and for many reasons, as an opportunity. It was an opportunity to use those buildings which had a real identity in this part of the 12th arrondissement, to invent a new neighbourhood, to find the right balance between transformation of the old and creation of new buildings and to achieve acceptable density in a very dense city. It was an opportunity to invent new types of housing and new uses while limiting the carbon footprint of the development operation.

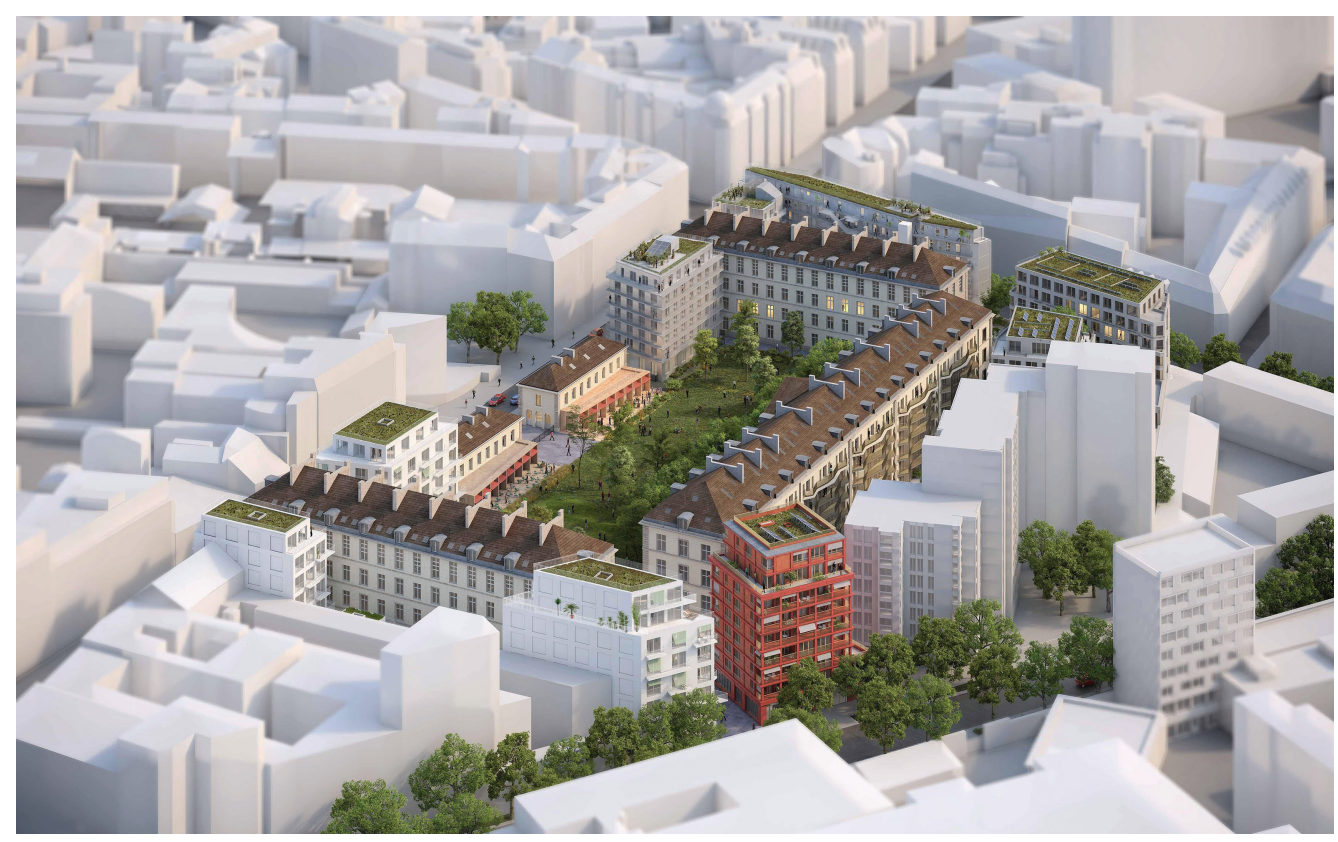

FIGURE 9.3 The New Vision for The Reuilly Barracks.

Source: Paris Habitat, TU VERRAS. 
Using the old buildings and the existing urban shape, while 'gently' inventing a new landscape and new buildings, no doubt led to increase the neighbourhood's population. However, the density remains a lot lower than the Parisian average. Only the buildings from the 1970s and 1980s - logistics, the army mail sorting facility and the officers' mess (a prefabricated building containing asbestos located in the middle of the parade ground) - were demolished.

With the preservation of the buildings and the demolition of those which could not be transformed, issues surrounding 'reuse' had to be considered by us and the project management teams from the design phase onwards. Paris Habitat enlisted the talents of a young Belgian agency, Rotor, to draw up an inventory of the site and analyse the life cycle of its components, the deconstruction of some elements and the conditions for their reuse with the same usage or their 'hijacking' for other purpose. Rotor worked in partnership with the different architect teams, and managed to integrate old materials into the new project while effectively contributing to improve the quality of the accommodation units and to the positive image of social housing.

Thanks to their work, it was possible to require the companies selected to do the construction works to consider reusing materials whenever possible. Here are a few examples of reuse on-site and off-site:

- The old iron radiators were refurnished and used in the new accommodation units;

- The oak cupboards from the old military offices were reconditioned and used as storage in the new accommodation units;

- The glass from the old windows was recycled as car windscreens by Saint Gobain;

- Concrete from demolition of the Barracks' mail sorting facility was crushed and partly used on-site for levelling the work sites;- the rest was sold to construction companies; and

- Recovery and adaptation of old cobblestones for public passageways and garden paths.

In short, in this reuse approach, waste was seen as a resource. With this project, Paris Habitat won a European award project, 'Charm', and received funding to roll out reuse in all its development projects: from construction to refurbishment of existing accommodation units and their reletting. The ecological transition of the Barracks, beyond developing buildings which encourage bioclimatic housing, also involved work to minimise the carbon impact of the project through the use of bio-sourced materials and decarbonised products for thermal insulation or the choice of wooden floors for some accommodation units and the nursery.

Like all programmes developed by Paris Habitat, it also required compliance with the City of Paris authorities' Energy Air Climate Plan which sets energy consumption goals. The City of Paris authorities allocate specific grants to help reach the goals of achieving $50 \mathrm{kWhpe} / \mathrm{m}^{2} \mathrm{FA} /$ year for new buildings and $80 \mathrm{kWhpe} / \mathrm{m}^{2} \mathrm{FA}$ /year for renovations. To achieve these ambitious goals, renewable energy and recycling, such as recycling grey water, form a considerable part of the programmes.

\section{The Place of Nature: Green and Public Spaces}

In many respects, preservation of the central empty space and reclaiming it as a real ecological opportunity for this new neighbourhood and for its future environmental quality was an important component of the redevelopment (Figure 9.4). Before even considering the creation of a public garden measuring nearly $5,000 \mathrm{~m}^{2}$, the asbestos-contaminated asphalt and the soil polluted by various activities performed on this site over many years had to be removed. The landscape designer and contractors took particular care to preserve the 11 existing plane trees in the ecological restoration. 




FIGURE 9.4 Site Plan and Urban Green Spaces.

Source: City of Paris/Paris Habitat.

In the months to come, this garden and the many trees it will house will ensure that warming and heat islands can be combated efficiently. The garden is complemented by the systematic re-vegetation of all the areas between the various buildings. Some of them will be for residents through the creation of a shared garden. Green flat roofs and areas within the student accommodation block will be taken care of by a not-for-profit organisation, Quartier Maraicher, to support the City of Paris authorities with their urban agriculture projects. They will grow vegetables and herbs, which will be sold to greengrocers and restaurants in the neighbourhood. They will also run workshops to raise awareness about agriculture with residents and children who attend the nearby schools. In total, more than $6,600 \mathrm{~m}^{2}$ are transformed into a public garden, Paris Habitat green spaces and green roofs.

The Reuilly Barracks is also home to a pair of common falcons (kestrels) who have been nesting there for a very long time. The presence of these protected birds had to be taken into account during the construction and renovation work. It was a real headache for the contractors when it came to defining the crane clearance areas during the nesting period or when the young kestrels were flying off the nest! Many were concerned that this space for the birds could be preserved, but expectations were met and at least 20 chicks were born during the operation.

\section{Housing Accessible to Diverse Households}

In total, 582 new accommodation units will be delivered between September 2019 and spring 2020:

- 209 social housing units divided into 100 PLUS, 61 PLAI and 48 PLS, and 129 student accommodation units funded via PLUS (studio flats) to house 140 young people;

- 110 PLI family accommodation units;

- 133 rent-controlled, private family accommodation units;

- A garden and public passageways covering more than $4,800 \mathrm{~m}^{2}$;

- A nursery for 66 children;

- Seven artist/artisan workshops; and

- Nine retail plots in the first round. 
TABLE 9.1 Monthly Rents per Square Metre

\begin{tabular}{|c|c|c|c|c|c|}
\hline \multirow[b]{2}{*}{ Operations } & \multirow[b]{2}{*}{$\begin{array}{l}\text { Local Increases } \\
(\%)\end{array}$} & \multicolumn{4}{|c|}{$\begin{array}{c}\text { Rent in } € \text { per } M^{2} \\
\text { per Month Depending on Category }{ }^{\mathrm{a}}\end{array}$} \\
\hline & & $\begin{array}{l}\text { Category } \\
\text { PLUS }\end{array}$ & $\begin{array}{l}\text { Category } \\
\text { PLAI }\end{array}$ & $\begin{array}{l}\text { Category } \\
\text { PLS }\end{array}$ & $\begin{array}{l}\text { Category } \\
\text { PLI }\end{array}$ \\
\hline Lot A - Logement Familial & 20 & 8.15 & 7.3 & 13.13 & \\
\hline Lot $\mathrm{A}-$ Etudiant & 20 & 11.12 & & & \\
\hline Lot C - Logement Familial & 20 & 8.28 & 7.35 & 12.96 & \\
\hline Lot C - PLI - Logement Familial & & & & & 16.81 \\
\hline Lot F - Logement Familial & 20 & 8.23 & 7.38 & 13.06 & \\
\hline Lot B1 - Logement Familial & 20 & 7.89 & 7.18 & 13.09 & \\
\hline
\end{tabular}

Source: City of Paris/Paris Habitat.

a Excluding charges, based on the building and the funding category.

Family accommodation range from studios to four bedrooms:

- 97 studio flats (from $18 \mathrm{~m}^{2}$ to $27 \mathrm{~m}^{2}$ );

- 20 large studio flats (from $27 \mathrm{~m}^{2}$ to $40 \mathrm{~m}^{2}$ );

- 561 -bedroom flats (from $40 \mathrm{~m}^{2}$ to $48 \mathrm{~m}^{2}$ );

- 158 2-bedroom flats (from $60 \mathrm{~m}^{2}$ to $70 \mathrm{~m}^{2}$ );

- 1073 -bedroom flats (from $70 \mathrm{~m}^{2}$ to $85 \mathrm{~m}^{2}$ ); and

- 14 4-bedroom flats (from $83 \mathrm{~m}^{2}$ to $95 \mathrm{~m}^{2}$ ).

It should be underlined that all the accommodation units can be accessed by people with reduced mobility. In view of the historic nature of Parisian property and the related accessibility problems, social housing stock plays an essential role in housing those with disabilities or reduced mobility. As mentioned above, the goal of the City of Paris authorities and of Paris Habitat is to develop housing with rents compatible with the incomes of a range of households, from the most vulnerable (those leaving the care system, those with a statutory right to housing, etc.) to the middle classes (teachers, civil servants, employees, etc.) (Table 9.1). Further, average fees for a student accommodation unit (from $18 \mathrm{~m}^{2}$ to $27 \mathrm{~m}^{2}$ ) amount to $€ 384 /$ month. These fees cover the rent, charges, furniture and availability of the communal areas (study room, launderette, etc.).

\section{Funding Social Housing: A French Model}

As detailed earlier, the project benefitted from a discounted purchase price. Moreover, the State and the City of Paris granted investment subsidies to make this program possible. Although social housing remains the responsibility of the State, this level of State support could no longer be achieved for a similar project. Since 2018, the French social housing system and its funding scheme are being revisited by the government, endangering the whole system. For instance, the State imposed a cut of up to $6.5 \%$ on the rent collected by social housing providers in order to reduce its own expenditures. Likewise, the Ile de France region has reduced its financial support for creating social housing (Taffin \& Amzallag, 2010). However, since 2001, the City of Paris authorities have made housing one of their priorities and have allocated a considerable budget to fund construction and renovation programmes and purchase real estate and property. Thus, between 2014 and the end of 2019, nearly $€ 3$ billion will have been mobilised for housing, including over 18 million euro for Reuilly Barracks (Table 9.2). 


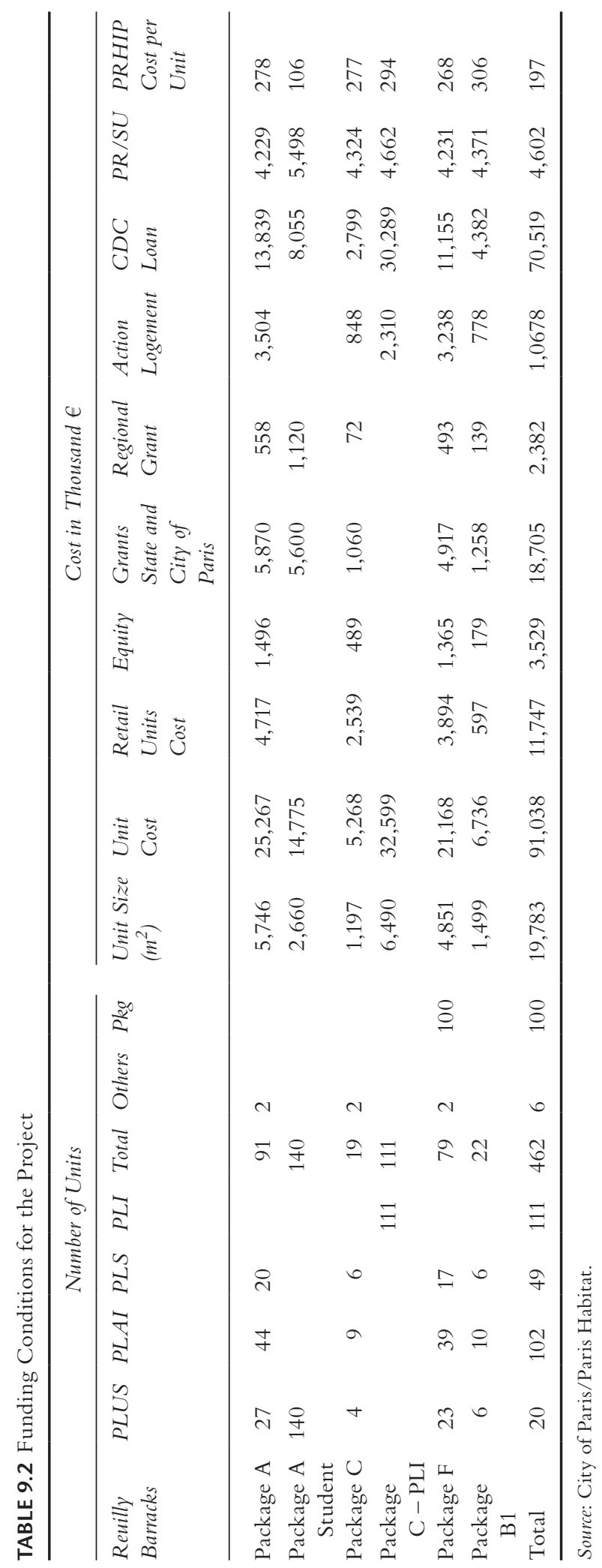


Since 2004, the City of Paris authorities set out annually their quantitative and qualitative goals in terms of development of new housing and renovation of existing buildings. They also spell out their requirements in terms of improvement in energy consumption. All these goals are laid out in an annual framework which also defines the investment subsidies the City will grant to the housing providers to meet these goals. This framework specifies the level of subsidies granted depending on the nature and location of the projects (Donzelat, 2012). The level of subsidies also depends on the category of social housing: a PLAI with very low rent will be more subsidised than a PLS with higher rent / more middle-class tenants, and PLI will not get any additional support.

Additional grants may be available, if, for instance, the project is located in an arrondissement with a social housing shortage or if it involves the regeneration of a substandard and unsafe property (insalubrious properties). Other considerations might include ambitious goals in terms of energy consumption or sustainable development. These grants make it possible to develop housing with accessible rents in a city where the cost of accommodation is prohibitive.

Note that the French social housing funding system is multilayered. The project therefore also benefitted from the other, traditional levers in the system: reduced VAT, reduced property tax during 25 years and a preferred funding mechanism via the French development bank, the CDC. (Refer to Table 9.2).

\section{Local Facilities}

Quality of life in Paris also depends upon the availability of retail spaces with stores and cafés. All housing development programmes therefore include retail premises. These spaces are designed to meet the needs and expectations of local and future residents. The choice of establishments depends on the location in Paris and is made with local partners. Some of these premises may be dedicated to non-commercial activities: not-for-profit, start-ups, cultural or craft-based, or community-oriented projects. However, in some areas, especially where property prices are very expensive, these premises are rented at market prices - the income generated contributes to the equilibrium of the project for the social housing provider. For the Reuilly Barracks, Paris Habitat worked with Semaest, an entity dedicated to economic development and also linked to the City of Paris. Semaest analysed the needs of local businesses, the neighbourhood and the uses of its inhabitants and held thereby what should be the priorities for the $4,000 \mathrm{~m}^{2}$ retail space of the project. The type of spaces and their purposes were defined through discussions with councillors, local residents and retailers in the neighbourhood (see Figure 9.5).

On this basis, calls for projects are being organised to choose the new businesses. A food court and a bookshop have already been chosen. The development of food trade apprenticeships and a partnership with training colleges in the area proposed by the future retailer were a determining factor. Therefore, the spaces located on rue de Chaligny, which are less commercially attractive, will be given over to not-for-profit organisations and institutional partners. Although not a medical desert like many places in France, rental costs for medical practices, doctor specialisation and prices above the State pricing system have reduced low-income residents' access to healthcare. Therefore, there are plans to use some spaces to set up a medical practice which, thanks to below-market rents, will enable doctors and paediatricians to practice and offer low fees. The Reuilly Barracks are located on the edge of Faubourg Saint Antoine, the historic artistic neighbourhood known for its cabinetmaking, and near the Boulle school (which teaches fine arts and crafts). It has therefore been decided to use some spaces to develop five artist and artisan workshops whose rents will help young people launch their careers.

In parallel with housing developments, the City of Paris authorities also aim to create facilities for young children. Given the lack of affordable real estate opportunities, these nurseries 

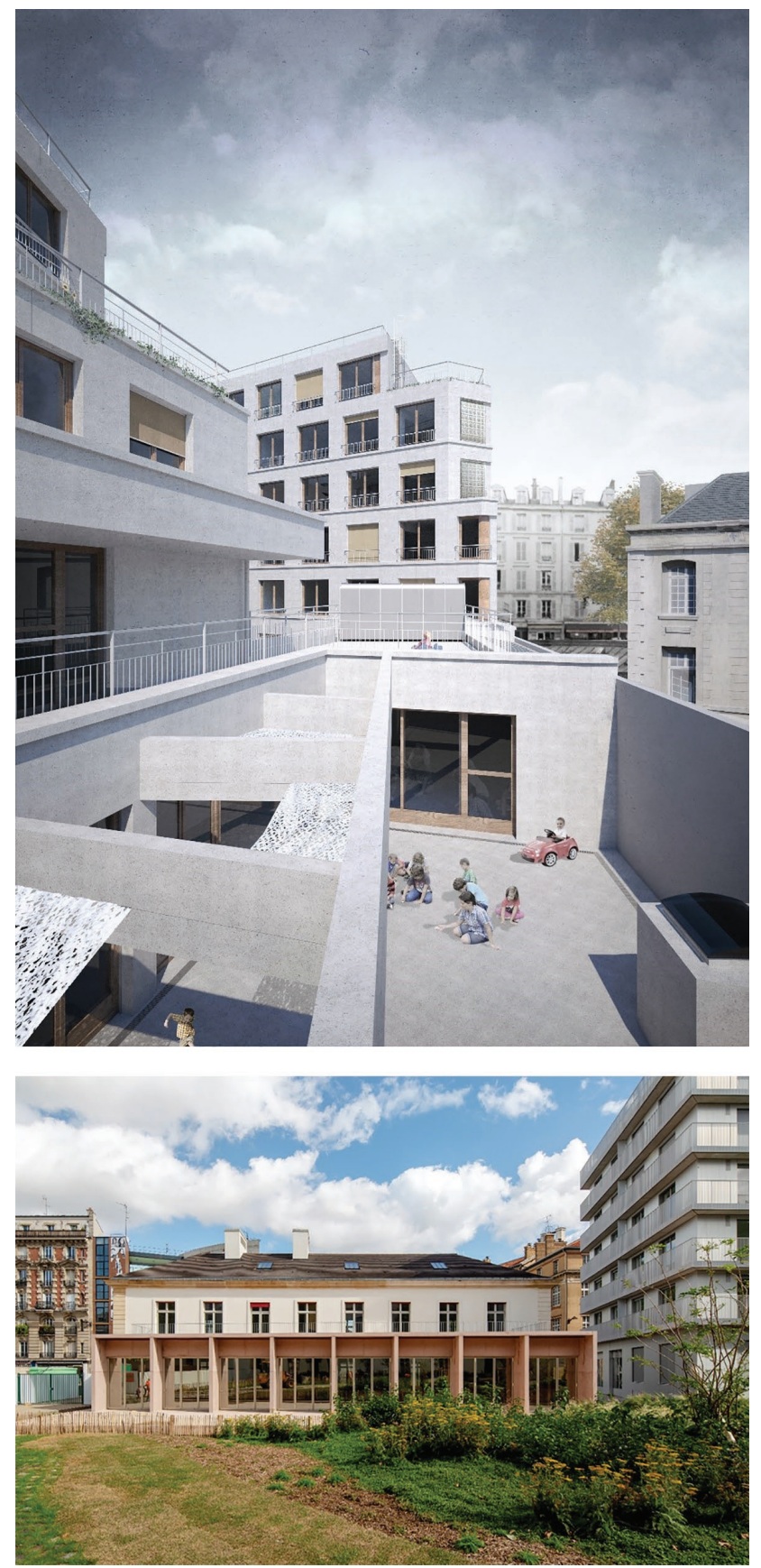

FIGURE 9.5 Nursery and Retail Stores.

Source: Paris Habitat, by Frédéric Delangle.

are often done together with the social housing projects. After studying the needs of the neighbourhood, the City instructed Paris Habitat to build a nursery for 66 children aged three months to three years. It was decided that the nursery would be established within the social housing programme (Package F) and developed on the second and third floors of the building. The facilities benefit from their own entrance from the courtyard, above street-level, away from the hustle and bustle of the street. The production cost of the nursery is $€ 5,800 \mathrm{~K}$, paid for by the City of Paris. 


\section{Conclusion: Paris Habitat Is a Local Player}

A diversity of housing is sought for all projects within each arrondissement (Paris' district). This case study responds to the ambitious goals of the City of Paris to increase its share of social housing. The development provides a mix of housing types to respond to different needs of residents, but also a sensitive integration of a variety of housing opportunities for low- and middle-income renters and homeowners. The funding model for social housing is an important defining element for the success of such developments, as is the regulatory and planning framework for the realisation of the 'SRU [urban solidarity and renewal] rate' in each arrondissement and local rebalancing issues (Taffin \& Amzallag, 2010).

For Paris Habitat, the preservation and the adaptive reuse of the Reuilly Barracks was a challenge, but also an opportunity to transform a historic place in a sustainable way, with an emphasis on social and environmental aspects. It was an opportunity to use those buildings which had a real identity in the 12th arrondissement, to invent a new neighbourhood, to find the right balance in the transformation of old buildings and to achieve density through high-quality design. It was an opportunity to invent new types of housing and new uses while limiting the carbon footprint of the development operation.

All programmes for adaptive reuse, such as the common garden, retail spaces and nursery, were the result of public engagement and co-design, leading to a shared vision for the place. With the preservation of the buildings and the sensitive new additions of housing with high energy-efficient performance, green roofs and diversity of opportunities for neighbourhood interaction, Reuilly Barracks is a new diverse community. Paris Habitat's commitment does not end with the construction project. We want to participate in the creation of a living community, bringing together current residents and future tenants and enable them to really feel part of their new neighbourhood. To do so, we organised various events to welcome everyone on the site, get them to know each other and meet Paris Habitat's staff who will be working there. As the first tenants move in, this beautiful project will become a lively neighbourhood.

\section{Acknowledgement}

This chapter was originally presented as a paper at an international symposium at the University of Calgary in 2019. We have used Paris Habitat materials and project documents to illustrate this unique example of award-winning redevelopment of heritage resources to accommodate the diverse housing needs of people in the city. Additional resources are available at www. parishabitat.fr/. Our thanks to Dr Tsenkova for the invitation to the symposium and for her kind support in the development of this chapter.

\section{References}

Atelier Parisien d'Urbanisme (APUR) (2014). L'évolution du logement social à Paris (Social Housing Development in Paris). Paris: Paris Urbanism Agency, www.apur.org/fr/nos-travaux/dernierschiffres-logement-social-paris.

Atelier Parisien d'Urbanisme (APUR) (2017). La ville autrement (The City By Other Means). Paris: Paris Urbanism Agency, www.apur.org/fr/nos-travaux/chiffres-logement-social-paris-2016-edition-2017

Bacqué, M. H. \& Gauthier, M. (2011) Participation, urbanisme et études urbaines. Quatre décennies de débats et d'expériences depuis. Participations, vol. 1: 36-66.

Donzelat, J. (2012) A quoi sert la rénovation urbaine? (What Purpose Does Urban Renewal Serve?), Paris: PUF, collection La ville en débat.

Driant, J. Cl. (2014). Enjeux et débats des politiques du logement en France, Revue d'économie financière. Association d'économie financière, vol. 0(3): 189-208.

Houdard, N. (2009) Droit au logement et mixité sociale (Right to Housing and Social Mix). Paris: L' Harmattan Collection, Habitat et Sociétés.

Taffin, C. \& Amzallag, M. (2010). Le logement social (Social Housing in France). Paris: Dexia L.G.D.J. 